\title{
Pneumoperitoneum Secondary to Emphysematous Cholecystitis: An Unusual Presentation
}

\author{
${ }^{1}$ Shailender Singh, ${ }^{2} \mathrm{KL}$ Surendra
}

\begin{abstract}
We herein report a case of emphysematous cholecystitis (EC) causing pneumoperitoneum with gross ascites, which is a very rare entity. A 64-year-old diabetic man was admitted with diffuse abdominal pain, abdominal distension and fever of 1 week duration. On examination, patient was febrile $\left(38.7^{\circ} \mathrm{C}\right)$ and abdominal guarding noted. Laboratory investigations revealed total leukocyte count of $16000 / \mu l$ with $90 \%$ neutrophils, total bilirubin level of $2 \mathrm{mg} / \mathrm{dl}$ (direct $0.60 \mathrm{mg} / \mathrm{dl}$ ). In erect X-ray abdomen, there was no significant finding. Ultrasonography (USG) abdomen showed cholelithiasis with thickened edematous gallbladder (GB) wall and few reflective echoes in GB fossa. Computed tomography (CT) axial sections revealed the presence of small stones in the gallbladder neck and small amount of intraluminal as well as intramural air. Tiny pockets of free intraperitoneal air was also noted. On intravenous (IV) contrast, there was minimal wall enhancement. Preoperative diagnosis of emphysematous cholecystitis with pneumoperitoneum was made and the same was confirmed in the intraoperative findings. Patient underwent emergency exploratory laparotomy with cholecystectomy and was given required medical management, the postoperative course was uneventful.
\end{abstract}

Keywords: Computed tomography scan, Emphysematous cholecystitis, Pneumoperitoneum.

How to cite this article: Singh S, Surendra KL. Pneumoperitoneum Secondary to Emphysematous Cholecystitis: An Unusual Presentation. Panam J Trauma Crit Care Emerg Surg 2014;3(1):39-41.

Source of support: Nil

Conflict of interest: None

\section{RESUMEN}

Estamos en este informe un caso de colecistitis enfisematosa causando neumoperitoneo con ascitis bruta, que es un muy rara entidad. Un hombre diabético de 64 años de edad que ingresó con difusa dolor abdominal, distensión abdominal y fiebre una semana duración. En el examen, el paciente estaba febril $\left(38,7^{\circ} \mathrm{C}\right)$ y defensa abdominal señaló. Las investigaciones

\footnotetext{
${ }^{1}$ Assistant Professor, ${ }^{2}$ Resident

1,2Department of Radiodiagnosis, Bangalore Medical College and Research Institute, Bengaluru, Karnataka, India

Corresponding Author: Shailender Singh, Assistant Professor, Department of Radiodiagnosis, Bangalore Medical College and Research Institute, Bengaluru, Karnataka, India Phone: 08041757082, e-mail: shail.bmc@gmail.com
}

de laboratorio revelaron recuento leucocitario total de $16000 / \mu \mathrm{l}$ con $90 \%$ de neutrófilos, el total de nivel de bilirrubina de $2 \mathrm{mg} /$ dl (directa 0,60 $\mathrm{mg} / \mathrm{dl}$ ). En erecto X-ray abdomen no había hallazgo significativo. USG abdomen mostró colelitiasis con engrosamiento de la pared GB edematosa y unos ecos de reflexión en la vesícula de la fosa de la vejiga. Computarizada secciones axiales de tomografía reveló la presencia de piedras pequeñas en el cuello de la vesícula biliar y la pequeña cantidad de intraluminal así como el aire intramural. Bolsas diminutas de aire libre intraperitoneal fue también señalado. En contraste IV, no hubo aumento de pared mínimo. El diagnóstico preoperatorio de colecistitis enfisematosa con neumoperitoneo se hizo y la misma fue confirmada en los hallazgos intraoperatorios. El paciente fue sometido de emergencia se le dio una laparotomía exploratoria con colecistectomía y el tratamiento médico necesario, el curso postoperatorio fue sin incidentes.

Palabras claves: Tomografía computarizada, Enfisematosa colecistitis, Neum-operitoneum.

\section{INTRODUCTION}

Emphysematous cholecystitis (EC) is a rare variant of acute cholecystitis, a potentially life-threatening condition secondary to infection by anaerobic organisms. ${ }^{8,12,13}$ This condition has a relatively high mortality rate which is approximately 15 to $20 \%{ }^{8,10}$ In contrast to acute cholecystitis, EC is more common in men, about half of them are diabetics, and gall stones present in less than $50 \%$ patients. ${ }^{13}$ Miyahara et al ${ }^{12}$ reported the 18th known case of EC with pneumoperitoneum in the English language in January 2013. We herein report the 19th known case. In the view of high mortality, awareness of EC as a cause of pneumoperitoneum is important, so that treatment will not be delayed. Of all the imaging techniques, computed tomography (CT) scan is the most sensitive and specific for diagnosis of this condition. ${ }^{10}$

The aim of this article is to present a case of emphysematous cholecystitis causing pneumoperitoneum and to demonstrate the specific ultrasonography (USG) and CT imaging findings.

\section{CASE REPORT}

A 64-year-old diabetic man was admitted with diffuse abdominal pain more at right upper quadrant, abdominal distension, nausea and fever of 1 week duration. On examination, patient was febrile $\left(38.7^{\circ} \mathrm{C}\right)$ and abdominal guarding noted. His vitals were stable and laboratory investigations 
revealed total leukocyte count of $16000 / \mu 1$ with $90 \%$ neutrophils, total bilirubin level of $2 \mathrm{mg} / \mathrm{dl}$ (direct $0.60 \mathrm{mg} / \mathrm{dl}$ ), hemoglobin-12.2 gm/dl, sodium-130 mEq/1, potassium-3.8 mEq/1, Blood urea nitrogen - $40 \mathrm{mg} / \mathrm{dl}$, serum creatinine $-1.6 \mathrm{mg} / \mathrm{dl}$, random blood sugar- $166 \mathrm{mg} / \mathrm{dl}$.

Erect X-ray abdomen which was done as an initial radiological investigation showed diffuse ground glass opacification of the abdomen.

At USG abdomen, gallbladder showed few echogenic luminal contents causing distal acoustic shadowing with edematous wall and reflective echoes causing dirty shadowing in gall bladder fossa (Fig. 1). These features were consistent with diagnosis of cholelithiasis and cholecystitis. Gross free fluid was also seen in peritoneal cavity. Computed tomography abdomen was done to rule out complications of cholecystitis and to know the cause for ascites.

Contrast enhanced computed tomography (CECT) axial sections of $1.3 \mathrm{~mm}$ thickness demonstrated the presence of small stones in the gallbladder (GB) neck and significant intraluminal as well as intramural air (Fig. 2). Tiny pockets of intraperitoneal free air also was also seen under the anterior abdominal wall (Fig. 3). On IV contrast, there was minimal GB wall enhancement. Gross ascites as well as minimal bilateral pleural effusion were also seen. The diagnosis of emphysematous cholecystitis (stage 2, air within GB wall) with pneumoperitoneum and gross ascites was made. ${ }^{5,10}$ Patient underwent emergency exploratory laparotomy and the GB was found to be gangrenous and very friable, hence the GB had to be resected in fragments and drain was kept in the GB fossa. Cultures from the GB fossa produced colonies of $E$. coli which was sensitive to piperacillin and amikacin. Patient needed intensive care unit (ICU) admission and was treated with IV piperacillin and tazobactam (Tazar) with amikacin for 2 weeks. During postoperative period, patient remained hemodynamically stable and was started on insulin for good glycemic control. Patient made an uneventful recovery during his course in the hospital.

\section{DISCUSSION}

Emphysematous cholecystitis is a rare variant and virulent form of acute cholecystitis characterized by the presence of air in the GB lumen and/or in the GB wall and also occasionally in the biliary tree with no abnormal communication between biliary system and the gastrointestinal (GI) tract. The condition is thought to begin as acute cholecystitis followed by ischemia (inflammatory edema leads to occlusion of the venous and lymphatic return from GB; eventually, arterial supply also compromised) or gangrene of the GB wall and infection by anaerobic organisms. ${ }^{6,7,11}$ The first described case of EC was by Stoltz A in 1901 at autopsy. ${ }^{1}$ Radiographically, the first case was reported in 1931 by Hegner. ${ }^{2}$ Emphysematous

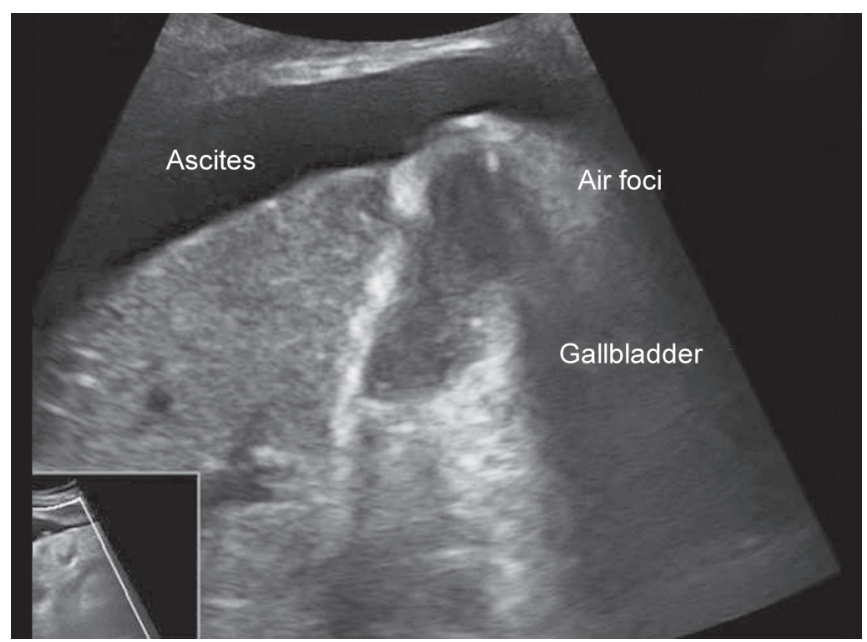

Fig. 1: Ultrasound of gallbladder (GB) shows cholelithiasis with foci of gas

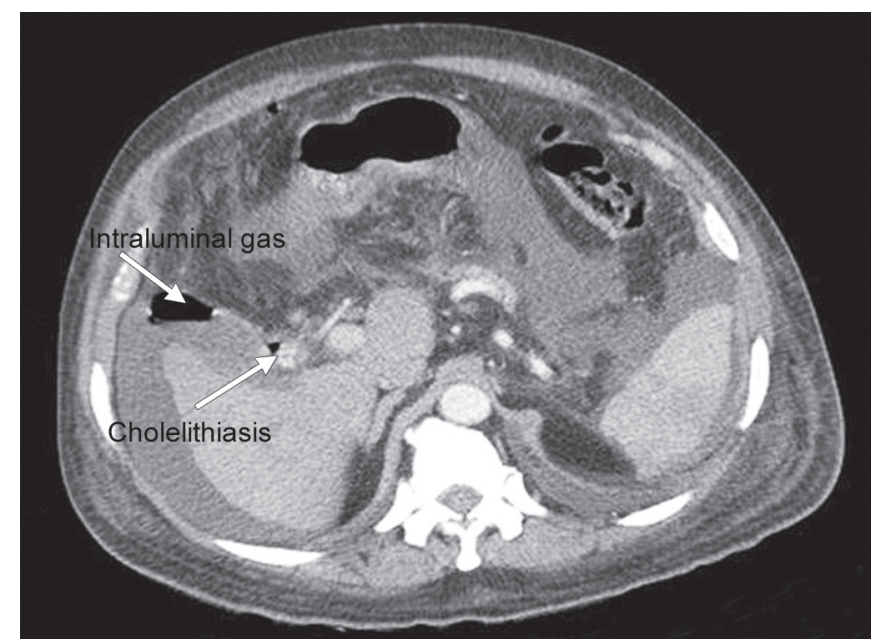

Fig. 2: Contrast enhanced CT at the level of GB shows cholelithiasis with intraluminal gas

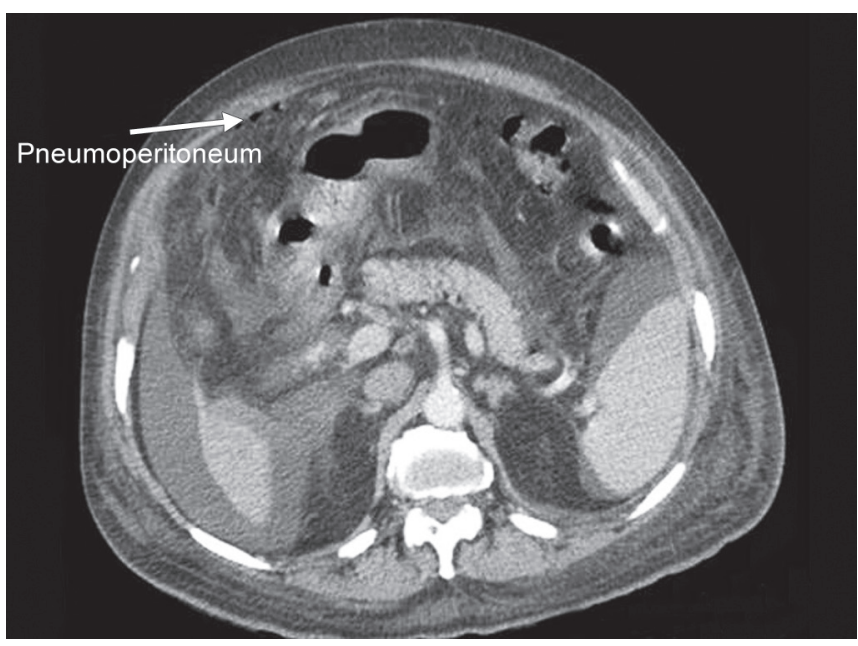

Fig. 3: Contrast enhanced CT at the level inferior to liver shows pneumoperitoneum

cholecystitis is graded according to distribution of air as follows: air in GB lumen (stage 1), air in the GB wall (stage 2) and air in pericholecystic tissues (stage 3). ${ }^{5,10}$ Our case belongs to stage 2 since air was present in GB wall as well as in lumen. 
In contrast to acute cholecystitis (females:males ratio $3: 7), \mathrm{EC}$ is more common in males compare to females $(7: 3)$ and up to 40 to $50 \%$ of patients are diabetics. ${ }^{5,6,12}$ In our case, there was history of diabetes mellitus since 15 years.

Clinically, patient can present with right upper quadrant abdominal pain, fever, nausea and even with symptoms of septic shock. Initially, symptoms can be vague and indistinguishable from uncomplicated acute cholecystitis. ${ }^{8,12}$ Peritoneal signs may be present, and right upper quadrant masses may be palpated in $50 \%$ of cases. ${ }^{12}$ In our case, patient presented with abdominal distension and right upper quadrant pain with fever and nausea; peritoneal signs and palpable mass were absent.

Plain radiographs can provide opportunity to identify abnormal gas collections in GB fossa as round bubbles or pear shaped lucency in the right upper quadrant in supine film or as air fluid level within GB in erect X-ray abdomen. ${ }^{8}$ Intraperitoneal free air also can be detected easily.

Ultrasonography abdomen is often first modality used for clinically suspected acute cholecystitis. Ultrasonography findings in EC include reverberation or 'comet tail' artifact due to change in acoustic impedance at soft tissue/gas interface. ${ }^{4}$ Gallbladder itself may not be visualized, due to reflection of sound waves by abnormal gas collections and there may be multiple tiny echogenic foci arising from GB lumen called 'effervescent' appearance or 'champagne bubbles' appearance. ${ }^{3}$ However, USG is less sensitive and specific to detect air within soft tissues compare to plain radiograph and CT scan. ${ }^{10}$ Adenomyomatosis of GB is an important differential diagnosis for reverberation or "comet tail' artifact, which can be definitively diagnosed with MRI. ${ }^{7}$ In our case, reflective echoes causing dirty shadowing in gallbladder fossa and cholelithiasis were noted.

Of all the imaging techniques, CT scan is the much closer to being $100 \%$ sensitive and most specific for detection of air within GB wall, lumen and in biliary system. ${ }^{5,8}$ It can also demonstrate local complications like pericholecystic inflammatory changes, perforation, abscess formation and even minute amounts of intraperitoneal free air. ${ }^{8} \mathrm{CT}$ scan can also help to exclude the close differential diagnoses of EC like cholecystoenteric fistula, GB lipomatosis and duodenal perforation. In our case, significant intraluminal and intramural air was present in GB fossa. ${ }^{10}$

The pathogens causing EC are anaerobes like Clostridium, and others, like E. coli, $P$. vulgaris, A. aerogenes, Staphylococcus and Streptococcus, Klebsiella and B. fragilis, that are able to produce gas in the process of decomposing glucose under anaerobic conditions. ${ }^{6,8}$ Off these, Clostridium welchiium, Clostridium perfringens and E. coli are mostly commonly cultured organisms in this setting. ${ }^{9}$
Emphysematous cholecystitis with concomitant pneumoperitoneum, which occurs due to GB wall perforation is a rare occurrence. Most of such patients are unstable. Therefore, first choice of treatment is emergency laparotomy followed by cholecystectomy. Other option is percutaneous cholecystostomy followed by second stage cholecystectomy. ${ }^{12}$ In all cases, adjuvant broad spectrum antibiotics should be used.

\section{CONCLUSION}

We herein reported a case of EC presenting with gross ascites and pneumoperitoneum. This condition is a very rare entity that carries a high mortality. Vascular compromise is the main reason for pathogenesis of disease. Ultrasonography and CT scan are most important diagnosing tools, CT being most accurate. Surgical intervention with antibiotic therapy is the mode of management. However, there is no consensus regarding the surgical options.

\section{REFERENCES}

1. Stolz A. Ubergasbildung in derGollinweger. Arch Pathol Anat 1901;165:90-123.

2. Hegner CF. Gaseous pericholecystitis with cholecystitis and cholelithiasis. Arch Surg 1931;22:993-1000.

3. Nemcek AA Jr, Gore RM, Vogelzang RL, Grant M. The effervescent gallbladder: a sonographic sign of emphysematous cholecystitis. Am J Roentgenol 1980;150:575-577.

4. Franquet T, Bescos JM, Barberena J, Montes M. Acoustic artifacts and reverberation shadows in gallbladder sonograms: their cause and clinical implications. Gastrointest Radiol 1990; 15:223-228.

5. Gill KS, Chapman AH, Weston MJ. The changing face of emphysematous cholecystitis. British J Radiol 1997;70:986-991.

6. Lallemand B, De Keulenner R, Maassaran F, et al. Emphysematous cholecystitis. Acta Chir Belg 2003;103:230-232.

7. Boscak AR, Al-Hawary M, Ramsburgh SR. Best cases from the AFIP: adenomyomatosis of the gallbladder. Radiogrpahics 2006;941-946.

8. Papavramidis TS, Michalopoulos A, Papadopoulos VN, Paramythiotis D, Karadimou V, Kokkinakis H, Fahantidis E. Emphysematous cholecystitis: a case report. Cases Journal 2008 August;1:73.

9. Wu JM, Lee CY, Wu YM. Emphysematous cholecystitis. Am J Surg 2010;200;e53-e54. DOI: 10.1016/j.amjsurg.2010.

10. Sunnapwar A, Raut AA, Nagar AM, et al. Emphysematous cholecystitis: imaging findings in nine patients. Indian J Radiol Imag 2011;21(2):142-146.

11. Miguel F. Carrascosa MD, José R. Salcines-Caviedes MD. Emphysematous cholecystitis. CMAJ 2012 January 10; 184(1):E81.

12. Miyahara H, Shida D, Matsunaga H, et al. Emphysematous cholecystitis with massive gas in the abdominal cavity. World J Gastroenterol 2013 Jan 28;19(4):604-606.

13. Adam AA, Dixon AKD, Grainger RGG, Allison DJA, Gibson R. 'The Biliary System' in Grainger and Allison's Diagnostic Radiology. 5th ed. London. United Kingdom: Churchill Livingstone Elsevier. 2008. p. 770. 